DOI: $10.14451 / 2.139 .7$

\title{
ПРАВОВЫЕ ПОЗИЦИИ СУДОВ В СФЕРЕ НАЛОГОВОГО И БЮДЖЕТНОГО КОНТРОЛЯ
}

\author{
(c) 2020 Казанкова Татьяна Николаевна \\ кандидат педагогических наук, доцент кафедры публичного права \\ Самарский государственный экономический университет, Россия, Самара \\ Email: tatianaok78@yandex.ru \\ (C) 2020 Мешалкина Анна Дмитриевна \\ студент-магистрант института права \\ Самарский государственный экономический университет, Россия, Самара \\ E-mail: anna-meshalkina6@mail.ru \\ (c) 2020 Маркович Анна Олеговна \\ студент-магистрант института права \\ Самарский государственный экономический университет, Россия, Самара \\ E-mail: kharitonova.anna96@mail.ru
}

В статье анализируются две отрасли государственного финансового контроля - в сфере налоговой и бюджетной деятельности. Рассмотрена правоприменительная практика судов, сформированная в налоговых и бюджетных правовых позициях, определено их значение в практическом осуществлении отраслей финансового контроля.

Ключевые слова: финансовый контроль, государственный финансовый контроль, налоговый контроль, бюджетный контроль, налоговые правовые позиции, Верховный Суд Российской Федерации, Арбитражный Суд, защита прав налогоплательщиков и налоговых органов, налоги.

Государственный финансовый контроль один из самых актуальных аспектов финансовой деятельности Российской Федерации. Контроль в системе органов исполнительной и законодательной власти занимает особе место. В юридической и экономической науках государственный финансовый контроль является составляющим звеном и инструментом для управления всеми финансами в государстве. Этот контроль реализуется на всех уровнях экономической жизни, в том числе на федеральном, региональном и на местном уровнях.

В данной статье мы будем рассматривать два вида финансового контроля: налоговый и бюджетный. Мы сделали аспект именно на эти два вида, так как в судебной практике встречаются интересные и спорные случаи. Правоприменительная практика в налоговом и бюджетном контроле своеобразна и имеет неоднозначный характер.

Начнем с понятия термина государственного финансового контроля. Существует огромное количество понятий и терминов, которые очень схожи с собой, имеют одинаковую правовую природу, иногда спорны друг с другом. Мы счи- таем, что значение этого термина следующее: это совокупность определённых мер, которые формируются, организовываются и осуществляются для обеспечения экономических ресурсов в государстве. Эти меры обосновывают использование денежных средств, а также выявляют нарушения использования денежных средств государства. Финансовый контроль существуют для организации органов, специализирующихся по изучению и выявлению установленных аспектов по использованию государственных средств.

Составная часть государственного финансового контроля заключается в надзоре над налоговой деятельностью, направленном на проведение проверки соответствия исполненных налоговых обязательств перед государством с фактической деятельностью налогоплательщика [1]. При осуществлении указанного вида государственного контроля возникают разногласия между налоговым органом и хозяйствующими субъектами, физическими лицами, разрешение которых не всегда возможно в административном порядке. Правовые позиции судов при разрешении споров по налоговому контролю представляются актуальной частью налоговых 
правовых позиций, полагаем необходимым обратиться к правоприменительной практике для рассмотрения указанного правового феномена.

При рассмотрении кассационной жалобы ПАО «Т Плюс» судебная коллегия Верховного суда Российской Федерации пришла к выводу о законности решений нижестоящих инстанций при определении допустимости отсутствия ограничений объемов проведения повторной выездной налоговой проверки [2]. Налогоплательщик имеет право на уточнение ранее поданной налоговой декларации, в случае ее представления налоговый орган наделен полномочиями по проведению выездной проверки в рамках соответствующего периода, который был заявлен к уточнению, то есть в части представленных изменений. Соответственно к возникшим правоотношениям не может быть применен срок ограничения глубины выездной проверки, составляющий три года, при проведении повторной выездной проверки после подачи уточненной декларации налоговый орган должен руководствоваться принципом разумности срока, который прошел с момента ее изменения. Разумность срока является оценочной категорий, которая подлежит соотнесению со всеми обстоятельствами, которые оказывают влияние на обеспечение баланса интересов, как частных, так и публичных. К числу указанных условий относятся возможность своевременного выявления внесения необоснованных уточнений в декларацию по изменению исчисления налога при наличии соответствующей организации контрольной работы налогового органа, в том числе при проведении повторной выездной проверки, с целью защиты публичных интересов по истечению четырехлетнего срока хранения документов, на основании которых происходит исчисление и уплата налогов (п. 1 ст. 23 НК РФ), а также определение наличия или отсутствия признаков противодействия налоговому органу при проведении контроля под налогоплательщиком. Бремя доказывания соблюдения требования разумности сроков проведения повторной выездной налоговой проверки возложено на налоговый орган (ч. 1 ст. 65, ч. 5 ст. 200 АПК РФ).Отсутствие в решениях судов оценки доводов налогового органа по вопросу обоснованности назначения повторной выездной проверки, не смотря на установление значительного срока ее назначения, составляющего 1 год 10 месяцев после представления уточненной налоговой де- кларации, привело к нарушению норм материального и процессуального права, что повлекло отмену решений нижестоящих инстанции и направление дела на новое рассмотрение.

Иной существенный аспект распределения бремени доказывания при проведении налогового контроля указан в постановлении Арбитражного суда Северо-Западного округа [3]. Налогоплательщик после приобретения строительных работ обратился в налоговой орган за получением вычета НДС, последним было в этом отказано, поскольку организация, которая фактически выполняла работы, применяла упрощенную систему налогообложения. Налоговый орган счел данное обстоятельство указывающим на наличие определенных расчетов и возвращений организации-заказчику должностными лицами контрагента, но не подтвердил это обстоятельство в суде, что свидетельствовало о недоказанности наличия сговора, целью которого являлось получение необоснованной налоговой выгоды. Суд пришел к выводу о том, что в решении налогового органа отсутствуют сведения о сокрытии в налоговой отчетности операций по исполнению работ, что могло повлечь необоснованное не начисление НДС с полученной выручки, также данное обстоятельство не нашло свое подтверждение в документах, представленных налогоплательщиком. При проведении налогового контроля за уходом от налогов необоснованный отказ в их возмещении является недопустимым, основанием для этого может быть установление фактов наличия сговора налогоплательщиков с наличием схем расчетов и возвращений денежных средств, что в указанном случае выявлено не было.

Процессуальное нарушение, допущенное налоговым органом и выраженное в несоблюдении срока составления акта, по результатам проведения налоговой проверки, не является безусловным основанием к его отмене по причине незаконности, поскольку указанное отступление не имеет предрешающего значения при рассмотрении данного акта. К такому выводу пришел Арбитражный суд Северо-Кавказского округа и изложил его в постановлении, обосновав указанное решение правовой сущностью п. 14 ст. 101 НК РФ [4]. Нарушения, допущенные налоговым органом, должны рассматриваться в совокупности с фактическими обстоятельствами дела и не могут служить основанием для препятствования в принятии итогового решения, 
вне зависимости от его сущности.

Осуществление реальных хозяйственных операций является существенным условием для расчета размера налоговой выгоды и понесенных затрат, в случае исчисления налога на прибыль с применением рыночных цен, которые соответствуют аналогичных сделкам [5]. ООО «ЭлектроТехМонтаж» по результатам выездной налоговой проверки были доначислены соответствующие налоги, пени и штрафы, поскольку налоговый орган пришел к выводу о нереальности финансово-хозяйственных сделок с рядом контрагентов. В результате налогового контроля было выявлено несоответствие фактической деятельности налогоплательщика с предоставленным им документальным подтверждением, в результате чего суд пришел к выводу об обоснованном доначислении налогов и соответствующих санкций в отношении указанного налогоплательщика, базирующемся на установлении факта получения необоснованной налоговой выгоды.

Недопустимым является осуществления мероприятий налогового контроля посредством осмотра территории и расположенных на ней помещений контрагентов проверяемого налогоплательщика или каких-либо третьих лиц, являющихся участниками сделок [6]. Указанное требование действует в случае неиспользования их с целью извлечения прибыли и содержания объектов налогообложения налогоплательщиком, в отношении которого проводятся мероприятия по налоговому контролю. Данные выводы изложены в решении Верховного Суда РФ, признавшего не действующим со дня принятия абзац седьмой письма Федеральной налоговой службы от 16 октября 2015 г. № С Д-4-3/18072 в указанной части.

При невозможности разрешения возникшего конфликта между налоговым органом и налогоплательщиком в административном порядке, каждая из сторон вправе обратиться за защитой своих прав и законных интересов в суд, посредством чего формируются правовые позиции судов в сфере налогового контроля. Решения судов имеют разную юридическую силу, часть из них являются общеобязательными для всех участников аналогичных правоотношений, иные - носят сугубо адресный характер, но вне зависимости от субъектов данная категория дел имеют особое значение для осуществления отрасли государственного финансового контроля - на- логового контроля.

Следующей составной частью финансового контроля является бюджетный контроль.

Бюджетный контроль - это одна из составных частей финансового контроля, с помощью которого регулируется экономическая деятельность органов создающих, рассматривающих, утверждающих проект бюджета. В последующем, после исполнения проекта бюджета и составление отчетной документации проверяются распределение и расходование бюджетных средств государства.

Актуальность данного вопроса заключается в том, что в российском законодательстве существует феномен перекоса в сторону государственных органов. Это происходит как в налоговом контроле, так и в бюджетном.

Вопрос о правильности распределения бюджетных средств напрямую исходит из вопроса о правильности сбора денежных средств. Чаще всего происходит спор о том, что объем налоговых выплат не пропорционален распределение бюджетных средств.

Чтобы рассмотреть данные аспекты более подробно необходимо обратиться к правоприменительной практике судов. Мы обратимся к ст. 306.4 Бюджетного кодекса Российской Федерации «Нецелевое использование бюджетных средств». Данную статью мы возьмем за основу, как пример функционирования бюджетного контроля. Именно нецелевое использование средств государства является одним из видов нарушения и применения бюджетного контроля в последующем.

Существует Постановление Пленума ВАС Российской Федерации от 22.06.2006 № 23 «О некоторых вопросах применения арбитражными судами норм Бюджетного кодекса Российской Федерации»: «Если судом будет установлено, что исходя из содержания перечней, наименований статей и подстатей Классификации невозможно с очевидностью установить, на какую статью (в случае, когда статья не детализирована подстатьями) или подстатью Классификации участнику бюджетного процесса следовало бы отнести осуществленные им расходы (т.е. когда названные расходы могли бы быть равным образом отнесены на различные статьи и подстатьи Классификации), финансирование указанных расходов за счет средств, выделенных на любую из возможных к применению статей или подстатей Классификации, не признается неце- 
левым использованием бюджетных средств.

Кроме того, не может быть применена ответственность за нецелевое использование бюджетных средств в случае оплаты за счет средств, выделенных на текущий финансовый год, соответствующих товаров, работ, услуг, которые будут поставляться, выполняться, оказываться в следующем финансовом году» [7], в котором говорится о том, что если в плане бюджета не будет конкретно определено на что именно будут распределены бюджетные средства, то данная классификация не признается нецелевым использованием бюджетных средств.

В деле А31-11366/2014, ООО «ЗубиК», который является получателем бюджетных средств, подало исковое заявление о признании незаконными принятых Территориальным фондом обязательного медицинского страхования субъекта РФ (Фондом) акта комплексной проверки и требования о восстановлении средств, использованных не по целевому назначению, и уплате штрафа [8].

Суд определил, что бюджетные средства не были классифицированы на заработную плату специалистов, у которых нет лицензии на исполнение своих профессиональных обязанностей. У работников с высшим и средним профессиональным образованием на момент получения заработной платы не было соответствующей лицензии Бюджетные средства выделялись исключительно Тарифным соглашением, в котором было прописано о том, что бюджетные денежные средства выделяются специалистам исключительно с действующей лицензией на момент получении заработной платы. Следовательно, судом было установлено, что бюджетные средства были направлены на нецелевое использование.

В данном деле представлены все аспекты исполнения бюджетного контроля. Именно нецелевое использование бюджетных средств очень частая статья судебных дел в бюджетном законодательстве. Органы власти очень четко курируют все обязательства, прописывают все структуры и тарифы получения бюджетных средств. К сожалению, наше законодательство не совсем верно регулирует вопрос о том, что именно относится к нецелевому использованию. Бюджетное законодательство имеет уклон к бюджетному контролю, а не к правильному исполнению и распределению денежных средств. Постановление Пленума ВАС, которые мы указали выше, как раз и трактует о некотором послаблении в контроле нецелевого использования для личных целей государственных органов.

Делая итоги, хочется отметить, что на сегодняшний день очень важен налоговый контроль и бюджетный. Они являются составными частями государственного финансового контроля, о являются одними из самых важных. Именно эти сферы очень тщательно регулируются государственными органами. Мы имеем не идеальное законодательство, которое обладает как феноменами, так и слишком правильным и тщательным подходом к «удобным» статьям кодексов. Все это позволяет сделать лишь один вывод: контроль в российском законодательстве всегда будет выполнять огромную роль.

\section{Библиографический список}

1. Thomas K.D. Presumptive Collection: A Prospect Theory Approach to Increasing Small Business Tax Compliance // Tax Law Review. 2013. Vol. 67. № 1. P. 119

2. Определение Судебной коллегии по экономическим спорам Верховного Суда РФ от 16.03.2018 № 305КГ17-19973 по делу № А40-230080/2016/ Справочная правовая система «КонсультантПлюс» [Электронный ресурс].- «Версия Проф», 2019.

3. Постановление Арбитражного суда Северо-Западного округа от 30.05 .2019 г. по делу № A13-15215/2015/ Справочная правовая система «КонсультантПлюс» [Электронный ресурс]. - «Версия Проф», 2019.

4. Постановление Арбитражного суда Северо-Кавказского округа от 31 мая 2019 г. № Ф08-4277/19 по делу № A53-24714/2018/ Справочная правовая система «КонсультантПлюс» [Электронный ресурс].- «Версия Проф», 2019.

5. Постановление Арбитражного суда Восточно-Сибирского округа от 22 мая 2019 г. по делу № A58-2537/2018/ Справочная правовая система «КонсультантПлюс» [Электронный ресурс]. - «Версия Проф», 2019.

6. Решение Верховного Суда РФ от 10.06.2019 № АКПИ19-296/ Справочная правовая система «КонсультантПлюс» [Электронный ресурс]. - «Версия Проф», 2019.

7. Постановление Пленума ВАС Российской Федерации от 22.06 .2006 № 23 «О некоторых вопросах применения арбитражными судами норм Бюджетного кодекса Российской Федерации» система «КонсультантПлюс» [Электронный ресурс]. - «Версия Проф», 2019. 
8. Постановление Арбитражного суда Волго-Вятского округа от 20 октября 2015 года. № Ф08-4277/19 по делу по делу N A31-11366/2014/Справочная правовая система «КонсультантПлюс» [Электронный ресурс].«Версия Проф», 2019. 